\title{
Production of Enniatins by Fusarium sambucinum: Selection of High-yield Conditions from Liquid Surface Cultures
}

\author{
By T. K. AUDHYA AND D. W. RUSSELL \\ Department of Biochemistry, Dalhousie University, Halifax, Nova Scotia, Canada
}

(Received 26 November 1973)

\section{SUMMARY}

Enniatins were determined in the mycelium of Fusarium sambucinum grown in liquid surface culture on semidefined or undefined media. Light was required for significant enniatin production, which was also favoured by moderate growth temperature. Production was supported by various carbon and nitrogen sources. Growth on a medium containing (w/v) $5 \%$ lactose and $0.8 \%$ tryptone, at $20^{\circ} \mathrm{C}$, with daily $\mathrm{I} 2 \mathrm{~h}$ photoperiods, yielded $\mathrm{I} \cdot 7 \mathrm{~g}$ enniatins/ 1 ( $10 \%$ of mycelial dry wt). Glucose inhibited sporulation of $F$. sambucinum.

Enniatin, named by Gäumann et al. (1947), is an antibiotic isolated from the mycelium of Fusarium orthoceras App. var. enniatinum. Lateritiins I and II, avenacein, fructigenin, and sambucinin (Cook, Cox, Farmer \& Lacey, 1947), obtained from various Fusarium isolates (Lacey, 1950), were thought to be similar but chemically distinct antibiotics (Cook, Cox \& Farmer, 1949), as was baccatin A obtained from Gibberella baccata (Guérillot-Vinet et al. I950). It is now known that all these substances are mixtures (Plattner \& Nager, 1948 $a$; Hall, I960; Audhya \& Russell, 1973a; A. H. Cook, personal communication) of isomeric and homologous cyclodepsipeptides (Russell, r966; Taylor, 1970) to which the general name 'enniatins' is applied.

Enniatins are cyclohexadepsipeptides of the general structure:

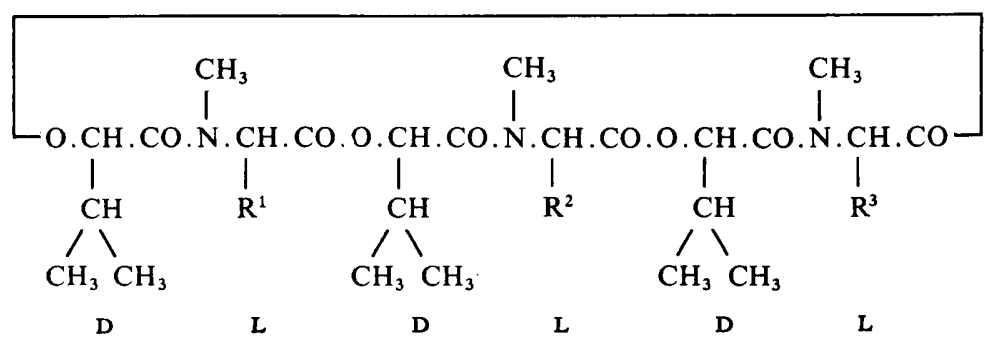

The only pure enniatin known to have been isolated from natural sources is enniatin $B$ $\left(\mathrm{R}^{1}=\mathrm{R}^{\mathbf{2}}=\mathrm{R}^{\mathbf{3}}=\right.$ isopropyl) obtained from Fusarium strains ETH4363 and ETHI574 (Plattner \& Nager, I $948 b$; Plattner, Nager \& Boller, 1948) and from $F$. avenaceum IMI 49894 (Tirunarayanan \& Sirsi, I957); it contains three residues of $N$-methyl-L-valine. Enniatin (Gäumann et al. 1947), subsequently called enniatin A (Plattner \& Nager, $1948 c$; Plattner et al. 1948$)$ is a mixture of 'true' enniatin $A\left(R^{1}=R^{2}=R^{3}=s\right.$-butyl) containing three residues of $N$-methyl-erythro-L-isoleucine (Shemyakin, Ovchinnikov, Kiryushkin \& Ivanov, I963 $b$; Plattner et al. 1963) together with homologues (Kiryushkin, Rozynov \& Ovchinnikov, I968) and stereoisomers (Audhya \& Russell, I973a) in which different R groups may be present in the same molecule. The presence of enniatin $C\left(R^{1}=R^{2}=R^{3}=\right.$ isobutyl; 
Ovchinnikov, Ivanov, Mikhaleva \& Shemyakin, 1964) in many Fusarium isolates has been inferred (Plattner \& Nager, 1948a) from chromatographic evidence of $N$-methyl-leucine in enniatin hydrolysates.

Enniatins are powerfully bioactive, apparently by interaction with membrane components. These properties are shared to some extent by the related cyclo-octadepsipeptide valinomycin (Brockmann \& Schmidt-Kastner, 1955; MacDonald, 1969), but there are differences, notably with regard to ion-selectivity (Shemyakin et al. 1969). Valinomycin is available commercially, but enniatins are not; enniatins A and B have been synthesized (Shemyakin et al. 1963a, b; Quitt, Studer \& Vogler, 1963; Plattner et al. 1963) but the syntheses require expensive materials and are technically demanding. This probably explains the relative neglect of enniatins in membrane research, and prompted us to reinvestigate fermentation as a cheap method of producing them in quantity (Audhya \& Russell, I973b). This paper describes enniatin production by a Fusarium sambucinum isolate in surface culture; the chemistry of these enniatins is described by Audhya \& Russell (1974).

\section{METHODS}

Organism. Fusarium sambucinum Fuckel, strain HLX316, was obtained from the Atlantic Regional Laboratory, National Research Council, Halifax, Nova Scotia, Canada, where it was maintained on $2 \%$ malt agar slants ( $20 \mathrm{~g}$ malt extract and $\mathrm{I} 5 \mathrm{~g}$ agar/l). In our laboratory it was subcultured on to potato + sucrose agar slopes (extractive from $200 \mathrm{~g}$ unpeeled potatoes, plus $20 \mathrm{~g}$ sucrose and $20 \mathrm{~g}$ agar/l), grown at $20^{\circ} \mathrm{C}$ for $2 \mathrm{I}$ days, then stored at $4{ }^{\circ} \mathrm{C}$. Subcultures were made at six-month intervals.

Preparation of inoculum. Ten days before inoculum was required, subcultures were made into Petri dishes containing potato + sucrose agar. A slope culture was flooded with sterile water, and the surface was rubbed gently with a stout platinum loop to obtain a mycelial suspension; $0.2 \mathrm{ml}$ was distributed evenly over the medium. Plates were incubated for 7 to Io days at $20{ }^{\circ} \mathrm{C}$. Four discs, $\mathbf{I} \cdot 2 \mathrm{~cm}$ in diam, were cut from the culture with a sterile corkborer and added to $500 \mathrm{ml}$ sporulation medium in a 2.81 Fernbach flask. After vigorous magnetic stirring for 65 to $70 \mathrm{~h}$ at $20^{\circ} \mathrm{C}$ the culture consisted almost entirely of spores, $25-35 \times 3-4 \mu \mathrm{m}$, with 3 or 4 transverse septa. The suspension was strained aseptically through a single layer of cellulose tissue (Kimwipes type $900 \mathrm{~S}$; Kimberley-Clark of Canada Ltd) and centrifuged at $2000 \mathrm{~g}$ for $10 \mathrm{~min}$, and the pellet was suspended in sterile water. Spores were counted in a haemocytometer, and the suspension was adjusted to contain $5 \times 10^{6}$ spores $/ \mathrm{ml}$.

Media. Culture media were sterilized by heating at $\mathrm{I} 2 \mathrm{I}^{\circ} \mathrm{C}$ for $25 \mathrm{~min}$ in an autoclave.

Sporulation medium contained: sodium acetate trihydrate, $2 \mathrm{~g}$; Bacto-tryptone, $2 \mathrm{~g}$; $\mathrm{KCl}, 0.25 \mathrm{~g} ; \mathrm{MgSO}_{4} .7 \mathrm{H}_{2} \mathrm{O}, 0.25 \mathrm{~g} ; \mathrm{KH}_{2} \mathrm{PO}_{4}, 0.5 \mathrm{~g} ; \mathrm{FeSO}_{4} .7 \mathrm{H}_{2} \mathrm{O}, 5 \mathrm{mg} ; \mathrm{Ca}\left(\mathrm{NO}_{3}\right)_{2} .4 \mathrm{H}_{2} \mathrm{O}$, $30 \mathrm{mg}$; trace-metal solution (Butler, Russell \& Clarke, 1962 ), $5 \mathrm{ml}$; and distilled water to $\mathrm{I} 1$. To determine the effect of carbon source and concentration on sporulation, the sodium acetate was altered in concentration or replaced by another carbon compound.

Semidefined medium contained: glucose, $30 \mathrm{~g}$; Bacto-tryptone, $3.8 \mathrm{~g} ; \mathrm{KCl}, 0.5 \mathrm{~g}$; $\mathrm{MgSO}_{4} .7 \mathrm{H}_{2} \mathrm{O}, 0.5 \mathrm{~g} ; \mathrm{KH}_{2} \mathrm{PO}_{4}$, I g; $\mathrm{FeSO}_{4} .7 \mathrm{H}_{2} \mathrm{O}$, ro mg; $\mathrm{Ca}\left(\mathrm{NO}_{3}\right)_{2} .4 \mathrm{H}_{2} \mathrm{O}, 60 \mathrm{mg}$; tracemetal solution, $10 \mathrm{ml}$; and distilled water to $\mathrm{I} 1$. The $\mathrm{pH}(6 \cdot 0$ before sterilization) was not adjusted. To determine the effects of carbon and nitrogen sources and concentrations on enniatin yield, the glucose and/or tryptone were altered in concentration or replaced by other carbon and/or nitrogen sources.

Standard potato + carrot extract (Done, Mortimer, Taylor \& Russell, I96I) was prepared 
as described by Okotore \& Russell (I972); the $\mathrm{pH}$ was adjusted to 5.5 with $\mathrm{N}-\mathrm{H}_{2} \mathrm{SO}_{4}$ before sterilization.

Other media used in preliminary experiments were the ones of Gäumann et al. (1947), Cook et al. (1949) and Cappellini \& Peterson (1969); in the latter, two sodium acetate concentrations were used.

Cultivation of organism. The medium was dispensed in $167 \mathrm{ml}$ portions into I 1 Pyrex Roux bottles, which then were closed with non-absorbent 'diSPo'-plugs $(\mathrm{I} \cdot 5 \times 2$ in; American Hospital Supply Co.) and sterilized. The cooled vessels were incubated at $20{ }^{\circ} \mathrm{C}$ for 3 days. Then, if no contamination was apparent, the media were inoculated with $2 \mathrm{ml}$ spore suspension, which was stirred magnetically to ensure a uniform inoculum. The vessels were incubated at $20^{\circ} \mathrm{C}$.

Each shelf (I $5 \times 60 \mathrm{~cm}$ ) was equipped with two parallel $4 \mathrm{ft}$ fluorescent lamp holders, $20 \mathrm{~cm}$ apart, bearing Deluxe cool-white lamps (General Electric of Canada Ltd). The lamps were fastened $45 \mathrm{~cm}$ above the shelf and were controlled by a common timer. The Roux bottles were laid horizontally in a single layer on the shelves; the intensity of illumination at their surface was approximately I080 lux. Culture temperature was maintained at $\pm \mathbf{I}{ }^{\circ} \mathrm{C}$ of the reported value, by air blown gently across each shelf. Unless otherwise stated, all cultures (including slopes, plates, and spore suspensions) were grown at $20^{\circ} \mathrm{C}$ with a daily I $2 \mathrm{~h}$ photoperiod.

Cultures were filtered in batches of six on a Büchner funnel, by using Whatman No. 5 filter paper. The mycelium was washed with two $500 \mathrm{ml}$ portions of distilled water, and left under suction for $4 \mathrm{~h}$. The combined filtrate and washings were mixed, and their volume was measured. Samples were stored at $-16^{\circ} \mathrm{C}$ until analysed. The moist mycelium was weighed, then homogenized for $5 \mathrm{~min}$ in methanol $(2 \mathrm{ml} / \mathrm{g})$. The suspension was centrifuged at $2500 \mathrm{~g}$ for Io min, and the supernatant extract was clarified by passage through a coarse sinteredglass filter. The pellet was re-extracted twice in the same way, and the combined clarified extracts were evaporated to dryness in vacuo at $50^{\circ} \mathrm{C}$. The residue and mycelial pellet were dried to constant weight in vacuo over $\mathrm{NaOH}$ flakes, and the weights were added to obtain the mycelial dry weight. The extractive was dissolved in chloroform and treated with cellulose, charcoal, and aluminium oxide (Audhya \& Russell, I973b) to give a mixture of enniatins and neutral lipids. All enniatin analyses were made on material brought to this stage of purification.

Analyses of medium constituents. Nitrogen was determined by a micro-Kjeldahl method (Chibnall, Rees \& Williams, I943); reducing sugars by the method of Hanes (I929), using a standard of the appropriate sugar; and sucrose by the method of Dubois et al. (I956), after hydrolysis in $0.5 \mathrm{~N}-\mathrm{HCl}$ at $100{ }^{\circ} \mathrm{C}$ for $15 \mathrm{~min}$. Glycerol was determined by a semi-micro adaptation of the method of Lambert \& Neish (I950). To the sample (I ml) containing glycerol (I to Io $\mu \mathrm{g}$ ) was added $0.5 \mathrm{ml} \mathrm{N}-\mathrm{H}_{2} \mathrm{SO}_{4}$ and $0.2 \mathrm{ml} 0.05 \mathrm{M}-\mathrm{NaIO}_{4}$, followed Io min later by $0.2 \mathrm{ml} 0.5 \mathrm{M}-\mathrm{NaAsO}_{2}$. After a further Io min, $5 \mathrm{ml}$ of $0.2 \%(\mathrm{w} / \mathrm{v})$ chromotropic acid was added and the mixture was heated in a boiling water bath for $45 \mathrm{~min}$. The solution was cooled to room temperature; absorbance was measured at $570 \mathrm{~nm}$, and the glycerol concentration was determined by reference to a standard curve. Analyses of medium constituents were in duplicate and results were averaged.

Enniatins were determined as enniatin $\mathrm{A}$ in the (enniatin + neutral lipid) mixtures. Each sample ( 5 to $25 \mathrm{mg}$ ) was hydrolysed in a sealed tube with a mixture of concentrated hydrochloric and glacial acetic acids (I: $\mathrm{I}, \mathrm{v} / \mathrm{v} ; \mathrm{I} \mathrm{ml}$ ) for $24 \mathrm{~h}$ at $\mathrm{I} \mathrm{IO}^{\circ}{ }^{\circ} \mathrm{C}$, and excess acid was removed in vacuo over $\mathrm{NaOH}$ flakes. The residue was dissolved in $\mathrm{I} \mathrm{ml}$ water, and total $\mathrm{N}$-methylamino acids were determined by quantitative paper chromatography, or by spectro- 
Table I. Formation of macroconidia by Fusarium sambucinum in shake-flask culture at $20{ }^{\circ} \mathrm{C}$ with a daily $12 \mathrm{~h}$ photoperiod

$\begin{array}{clcccc}\text { Medium } & \begin{array}{c}\text { Carbon source } \\ (\mathrm{mg} \mathrm{C} / \mathrm{ml})\end{array} & 24 \mathrm{~h} & 48 \mathrm{~h} & 72 \mathrm{~h} & 96 \mathrm{~h} \\ \mathrm{I}^{*} & \text { Na acetate (6) } & 0.5 & \mathrm{I} \cdot 2 & \mathrm{I} \cdot 8 & 2 \cdot 9 \\ & \text { Na acetate (0.6) } & \mathrm{I} \cdot \mathrm{I} & 3 \cdot 4 & 3 \cdot 9 & 4 \cdot \mathrm{I} \\ 2 \dagger & \text { Na acetate (6) } & 2 \cdot 3 & 4 \cdot 9 & 6.7 & 7.9 \\ & \text { Glucose (6) } & 0.4 & 0.5 & 0.6 & 0.5 \\ & \text { Na acetate (0.6) } & - & - & 8 \cdot 0 & - \\ & \text { Na citrate (0.6) } & - & - & 9 \cdot 5 & - \\ & \text { Na pyruvate (0.6) } & - & - & 30.5 & -\end{array}$

* The medium of Capellini \& Peterson (1969) containing sodium acetate at the carbon concentrations indicated.

$\dagger$ The sporulation medium described in the text containing carbon sources at the concentrations indicated.

photometry using 2,4,6-trinitrobenzenesulphonic acid and ninhydrin (Audhya \& Russell, $1973 \mathrm{c}$ ). The result (mg of $N$-methylisoleucine/mg of sample) was multiplied by the theoretical factor $\mathrm{I} \cdot 57$ to give total enniatins as enniatin A. Analyses were in duplicate and the results averaged.

\section{RESULTS}

Fusarium sambucinum HLX316 formed many macroconidia when grown on the medium of Cappellini \& Peterson (1969) in shake flasks at two concentrations of sodium acetate. At half strength the semidefined medium gave fewer spores, but when glucose was replaced by the sodium salt of an organic acid there was abundant sporulation (Table I). Inhibition of sporulation by glucose accords with the similar observation of Cappellini \& Peterson (1969) using Gibberella zeae. Sodium pyruvate was an excellent carbon source for sporulation by F. sambucinum, but for routine inoculum preparation we used the cheaper sodium acetate.

Gäumann et al. (1947) obtained enniatins from the mycelium of Fusarium orthoceras, and Plattner et al. (1948) found very small amounts in Fusarium culture filtrates. We determined enniatins in the mycelium only. In our early trials, Soxhlet extraction of dried mycelium with methanol or other solvents removed enniatins only slowly. However, extraction of enniatins from moist mycelium with cold methanol, as described by MacDonald (1969) for isolating valinomycin from Streptomyces, was rapid; the last extract of $F$. sambucinum mycelium thrice extracted in this way contained only traces of enniatins, and no more was obtained by overnight Soxhlet extraction of the residue.

Initially, Fusarium sambucinum was grown for $2 \mathrm{I}$ days at $25^{\circ} \mathrm{C}$ with a daily $8 \mathrm{~h}$ photoperiod. Enniatin yields $(\mu \mathrm{g} / \mathrm{ml})$ on four media were: o (Cook et al. 1949); 25 (Gäumann et al. 1947); 72 (semidefined medium); and I 47 (potato + carrot extract). The last two media were selected for further study. Enniatins appeared only when growth had almost ceased and the nitrogen in the medium had become minimal (Table 2); once formed, they appeared stable for several weeks. The amounts formed were considerably greater on potato + carrot than on the semidefined medium, but considerably less than reported by Plattner et al. (1948).

\section{Effects of temperature and lighting}

(i) The organism was grown on potato + carrot medium with a daily $8 \mathrm{~h}$ photoperiod at three temperatures, and the residual nitrogen in the medium was determined every 3 days. Cultures were harvested after about $\mathrm{I} \cdot 5$ times the time required to reach minimal residual 
Table 2. Growth, utilization of medium constituents, and enniatin production by Fusarium sambucinum in surface culture at $25^{\circ} \mathrm{C}$ with a daily $8 \mathrm{~h}$ photoperiod

\begin{tabular}{|c|c|c|c|c|c|c|c|c|c|c|}
\hline \multirow{3}{*}{$\begin{array}{l}\text { Time } \\
\text { after } \\
\text { inocu- } \\
\text { lation } \\
\text { (days) }\end{array}$} & \multicolumn{6}{|c|}{ Medium analyses* } & \multicolumn{4}{|c|}{ Mycelium analyses } \\
\hline & \multicolumn{2}{|c|}{$\mathrm{pH}$} & \multicolumn{2}{|c|}{$\begin{array}{l}\text { Reducing sugar } \\
(\mathrm{mg} / \mathrm{ml})\end{array}$} & \multicolumn{2}{|c|}{$\begin{array}{l}\text { Nitrogen } \\
(\mathrm{mg} / \mathrm{ml})\end{array}$} & \multicolumn{2}{|c|}{$\begin{array}{l}\text { Dry weight } \\
(\mathrm{mg} / \mathrm{ml})\end{array}$} & \multicolumn{2}{|c|}{$\begin{array}{l}\text { Enniatins } \\
(\mathrm{mg} / \mathrm{l})\end{array}$} \\
\hline & A & $\mathbf{B}$ & A & B & A & $\vec{B}$ & $\mathbf{A}$ & B & $\mathbf{A}$ & $\mathbf{B}$ \\
\hline 8 & $4 \cdot 6$ & $7 \cdot 8$ & 0.65 & $I \cdot 42$ & 0.24 & 0.15 & $5 \cdot 8$ & $8 \cdot 4$ & 0 & 0 \\
\hline 16 & $6 \cdot 1$ & $8 \cdot 4$ & 0.55 & 0.67 & 0.16 & 0.05 & $8 \cdot 2$ & $7 \cdot 1$ & 41 & 163 \\
\hline 22 & $6 \cdot 9$ & $8 \cdot 7$ & 0.46 & 0.60 & 0.13 & 0.28 & 6.2 & $6 \cdot 4$ & 47 & 159 \\
\hline 30 & $7 \cdot 2$ & $8 \cdot 8$ & 0.55 & 0.70 & 0.15 & 0.26 & $5 \cdot 5$ & $6 \cdot 1$ & 66 & 152 \\
\hline 38 & $7 \cdot 65$ & 8.9 & 0.45 & 0.63 & 0.23 & 0.29 & $5 \cdot 0$ & $5 \cdot 4$ & 57 & 72 \\
\hline 45 & $7 \cdot 6$ & $9 \cdot 0$ & 0.40 & 0.55 & 0.25 & 0.25 & $4 \cdot 9$ & $5 \cdot I$ & 15 & 23 \\
\hline
\end{tabular}

A, on semidefined medium; $B$, on potato + carrot extract.

* Initial values, for $\mathrm{A}$ and $\mathrm{B}$ respectively: $\mathrm{pH}, 6.0$ and 5.5 ; reducing sugar, 30 and $10 \mathrm{mg} / \mathrm{ml}$; nitrogen, 0.475 and $0.53 \mathrm{mg} / \mathrm{ml}$.

Table 3. Effects of temperature on enniatin production by Fusarium sambucinum grown in surface culture on semidefined medium with a daily $8 \mathrm{~h}$ photoperiod

$\begin{array}{cccccc}\begin{array}{c}\text { Incubation } \\ \text { temperature } \\ \left({ }^{\circ} \mathrm{C}\right)\end{array} & \begin{array}{c}\text { Minimal N* } \\ (\mathrm{mg} / \mathrm{ml})\end{array} & \begin{array}{c}\text { Time to } \\ \text { minimal N } \\ \text { (days) }\end{array} & \begin{array}{c}\text { Time of } \\ \text { harvest } \\ \text { (days) }\end{array} & \begin{array}{c}\text { Dry wt } \\ (\mathrm{mg} / \mathrm{ml})\end{array} & \begin{array}{c}\text { Enniatins } \\ (\mathrm{mg} / \mathrm{l})\end{array} \\ 20 & 0.08 & 24 & 37 & 5.75 & 376 \\ 25 & 0.10 & 15 & 24 & 5.9 & 66 \\ 30 & 0.10 & 6 & 11 & 4 \cdot 6 & 47 \\ & & & & & \end{array}$

Table 4. Effect of photoperiod on enniatin production by Fusarium sambucinum grown in surface culture for 2I days on potato + carrot medium at $25^{\circ} \mathrm{C}$

$\begin{array}{ccc}\begin{array}{c}\text { Light } \\ \text { (h/day) }\end{array} & \begin{array}{c}\text { Dry wt } \\ (\mathrm{mg} / \mathrm{ml})\end{array} & \begin{array}{c}\text { Enniatins } \\ (\mathrm{mg} / \mathrm{l})\end{array} \\ \circ & 4 \cdot 8 & 4 \mathrm{I} \\ 8 & 6 \cdot 5 & 158 \\ 12 & 6 \cdot 2 & 170 \\ 24 & 5 \cdot 6 & 125\end{array}$

nitrogen (standard growth period). Enniatin production was very much greater at $20^{\circ} \mathrm{C}$ than at 25 or $30^{\circ} \mathrm{C}$ (Table 3). This experiment was repeated, with similar results.

(ii) The organism was grown at $25^{\circ} \mathrm{C}$ on potato + carrot medium with a varied daily photoperiod and was harvested after $2 \mathrm{I}$ days. Enniatin production was much less in darkness than in light, but the length of the photoperiod was not critical in the range studied (Table 4). This experiment was repeated, with similar results.

\section{Effects of carbon and nitrogen concentrations and sources on enniatin yield}

In these experiments the more reproducible semidefined medium was used as a standard. All cultures were grown at $20^{\circ} \mathrm{C}$ with a daily $\mathrm{i} 2 \mathrm{~h}$ photoperiod.

Effect of glucose concentration. The organism was grown on semidefined medium containing various concentrations of glucose and cultures were harvested after the standard growth period. Good enniatin yields were obtained in the range 12.5 to $30 \mathrm{mg}$ glucose $/ \mathrm{ml}$; 
Table 5. Effect of glucose concentration on enniatin production by Fusarium sambucinum in surface culture on semidefined medium at $20^{\circ} \mathrm{C}$ with a daily $12 h$ photoperiod

$\begin{array}{ccccc}\begin{array}{c}\text { Initial glucose } \\ (\mathrm{mg} / \mathrm{ml})\end{array} & \begin{array}{c}\text { Minimal N } \\ (\mathrm{mg} / \mathrm{ml})\end{array} & \begin{array}{c}\text { Time to } \\ \text { minimal } \\ \text { (days) }\end{array} & \begin{array}{c}\text { Time of } \\ \text { harvest } \\ \text { (days) }\end{array} & \begin{array}{c}\text { Enniatins } \\ (\mathrm{mg} / \mathrm{l})\end{array} \\ 6.25 & 0.15 & 9 & 14 & 79 \\ 12.5 & 0.11 & 13 & 22 & 360 \\ 25 & 0.10 & 22 & 34 & 490 \\ 30 & 0.10 & 29 & 47 & 440 \\ 50 & 0.09 & 37 & 57 & 187 \\ 60 & 0.09 & 41 & 63 & 110\end{array}$

Table 6. Effect of carbon source on enniatin production by Fusarium sambucinum in surface culture for 34 days on semidefined medium at $20^{\circ} \mathrm{C}$ with a daily $\mathrm{I} 2 \mathrm{~h}$ photoperiod

\begin{tabular}{lcccc}
\multicolumn{1}{c}{ Carbon source added } & $\begin{array}{c}\text { No. of } \\
\text { expts } \\
\text { Concentration } \text { I }^{*}\end{array}$ & $\begin{array}{c}\text { Mean } \\
\text { dry wt } \\
(\mathrm{mg} / \mathrm{ml})\end{array}$ & $\overbrace{\text { Mean }}$ & Range \\
Glucose & 5 & $6 \cdot 7$ & 354 & $320-382$ \\
Galactose & 2 & $6 \cdot 0$ & 305 & 295,316 \\
Lactose & 8 & $8 \cdot 9$ & 797 & $750-865$ \\
Glucose + galactose $\dagger$ & 2 & $5 \cdot 3$ & 299 & 289,310 \\
Maltose & 2 & $5 \cdot 4$ & 302 & 290,315 \\
Sucrose & 2 & $6 \cdot 5$ & 357 & 330,384 \\
Glycerol & 3 & $7 \cdot 7$ & 600 & $572-640$ \\
& Concentration & $2 \ddagger$ & & \\
None & 2 & $3 \cdot 0$ & 25 & 17,33 \\
Na acetate & 2 & $4 \cdot 9$ & $45 \mathrm{I}$ & 410,492 \\
Na citrate & 2 & $4 \cdot 1$ & 482 & 459,506 \\
Na lactate & 2 & $7 \cdot 8$ & 546 & 510,582
\end{tabular}

* Carbon compound at a concentration equivalent to $10 \mathrm{mg} \mathrm{C} / \mathrm{ml}$ and $0.5 \mathrm{mg}$ tryptone $\mathrm{N} / \mathrm{ml}$.

$\uparrow$ Each sugar was added at a concentration equivalent to $5 \mathrm{mg} \mathrm{C} / \mathrm{ml}$.

$\ddagger$ Carbon compound at a concentration equivalent to $6 \mathrm{mg} \mathrm{C} / \mathrm{ml}$ and $\mathrm{I} \mathrm{mg}$ tryptone $\mathrm{N} / \mathrm{ml}$.

higher concentrations were markedly inhibitory. The yield appeared optimal with a glucose concentration of $25 \mathrm{mg} / \mathrm{ml}$ (Table 5), an observation confirmed in two further experiments. The yields were similar when the glucose was autoclaved separately.

Effect of carbon source. A concentration of $25 \mathrm{mg}$ glucose $/ \mathrm{ml}$ corresponds to a carbon concentration of $10 \mathrm{mg} / \mathrm{ml}$. The organism was grown for 34 days on semidefined medium with this $\mathrm{C}$ concentration in various chemical forms. All sources were completely utilized except for lactose, $20 \%$ of which remained in the medium at harvest, and all supported enniatin production. Of the common sugars tested, lactose gave more than twice as much enniatin as any other; glycerol also was an excellent source (Table 6).

When similar comparison of the sodium salts of organic acids was attempted, the media rapidly became alkaline and growth ceased. Therefore, these compounds were used at a lower concentration $(6 \mathrm{mg} \mathrm{C} / \mathrm{ml})$, and the amount of tryptone was doubled for extra buffering. The results (Table 6), although not directly comparable to those obtained with carbohydrates and glycerol, showed that organic acids are good carbon sources for enniatin production.

Effect of nitrogen concentration. As enniatin production was greatest with lactose, this 
Table 7. Effect of tryptone concentration on enniatin production by Fusarium sambucinum grown for 34 days on semidefined medium* at $20^{\circ} \mathrm{C}$ with a daily $12 \mathrm{~h}$ photoperiod

$\begin{array}{ccc}\begin{array}{c}\text { Tryptone } \\ (\mathrm{mg} / \mathrm{ml})\end{array} & \begin{array}{c}\text { Unused lactose } \dagger \\ (\mathrm{mg} / \mathrm{ml})\end{array} & \begin{array}{c}\text { Enniatins } \\ (\mathrm{mg} / \mathrm{l})\end{array} \\ 2 & \mathbf{1 3} \cdot \mathrm{I} & 444 \\ 4 & 2 \cdot 9 & 797 \\ 6 & 0 \cdot 7 & 1 \mathrm{I87} \\ 8 & 0 \cdot 4 & 1208 \\ 12 & 14 \cdot 2 & 253\end{array}$

* Glucose replaced by lactose $(25 \mathrm{mg} / \mathrm{ml})$. $\dagger$ Remaining in the medium at harvest.

Table 8. Effect of nitrogen source on enniatin production by Fusarium sambucinum grown in surface culture for 34 days on semidefined medium at $20^{\circ} \mathrm{C}$ with a daily $\mathrm{I} 2 \mathrm{~h}$ photoperiod

\begin{tabular}{|c|c|c|c|c|}
\hline \multirow[b]{2}{*}{ Nitrogen source* } & \multirow{2}{*}{$\begin{array}{l}\text { No. of } \\
\text { expts }\end{array}$} & \multirow{2}{*}{$\begin{array}{c}\text { Mean } \\
\text { dry wt } \\
\text { (mg/ml) }\end{array}$} & \multicolumn{2}{|c|}{$\underset{(\mathrm{mg} / \mathrm{l})}{\text { Enniatins }}$} \\
\hline & & & Mean & Range \\
\hline $\mathrm{NH}_{4} \mathrm{NO}_{3}$ & 2 & $\mathbf{2 \cdot 2}$ & $6 \mathrm{I}$ & 54,69 \\
\hline $\mathrm{NaNO}_{3}$ & 2 & $7 \cdot 8$ & 910 & $879,94 \mathrm{I}$ \\
\hline Casein hydrolysate, enzymic & 2 & $7 \cdot 1$ & 1080 & 1040,1120 \\
\hline Tryptone & 4 & $9 \cdot 2$ & II47 & $1070-1190$ \\
\hline Glutamic acid & 2 & $I \cdot I$ & 0 & \\
\hline Glutamic acid $\dagger$ & 2 & 3.I & 0 & \\
\hline Asparagine & 2 & 0 & 0 & \\
\hline Asparagine $\dagger$ & 2 & $5 \cdot 8$ & 627 & 620,635 \\
\hline Urea & 3 & $6 \cdot I$ & 1062 & $865-1381$ \\
\hline
\end{tabular}

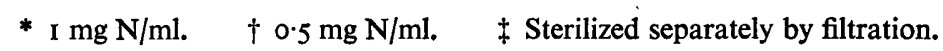

sugar was used in place of glucose in the semidefined medium, with tryptone at various concentrations. Enniatin yield and sugar utilization after 34 days' incubation were maximal with $8 \mathrm{mg}$ tryptone per $\mathrm{ml}$ (Table 7). More than $95 \%$ of the nitrogen was utilized except with the highest concentration, at which $60 \%$ remained in the medium at harvest.

Effect of nitrogen source. A tryptone concentration of $8 \mathrm{mg} / \mathrm{ml}$ corresponds to I $\mathrm{mg}$ nitrogen/ml. Fusarium sambucinum HLX3 I 6 was grown for 34 days on semidefined medium containing Io $\mathrm{mg}$ lactose $\mathrm{C} / \mathrm{ml}$, with I $\mathrm{mg} \mathrm{N} / \mathrm{ml}$ in various chemical forms. Media containing $\mathrm{NH}_{4} \mathrm{NO}_{3}$ rapidly became very acidic and produced little enniatin, but those containing $\mathrm{NaNO}_{3}$ or protein hydrolysates gave high yields. Tryptone was consistently the best source tested for enniatin production (Table 8).

Effect of $C / N$ ratio. Since lactose and tryptone, respectively, were the best carbon and nitrogen sources tested, the effect of varying their proportion was studied. Expt I: semidefined medium containing a standard amount of lactose (equivalent to $10 \mathrm{mg} \mathrm{C} / \mathrm{ml}$ ) was used with various tryptone concentrations. Expt 2: the initial tryptone concentration (equivalent to I mg N/ml) was kept constant and that of lactose varied. Expt 3: tryptone equivalent to $0.5 \mathrm{mg} \mathrm{N} / \mathrm{ml}$ was used with various glucose concentrations. The batch of tryptone used in these experiments contained $46.0 \% \mathrm{C}$ and $12.5 \% \mathrm{~N}$. C/N ratios were calculated from the expression

$$
\frac{\mathrm{C}}{\mathrm{N}}=\frac{0.46 C_{\text {tryptone }}+0.42 C_{\text {lactose }}}{0.125 C_{\text {tryptone }}}
$$

where $C$ is initial concentration $(\mathrm{mg} / \mathrm{ml})$. Cultures were harvested 34 days after inoculation and were analysed. 
Table 9. Effects of $C / N$ ratio on enniatin production by Fusarium sambucinum grown in surface culture for 34 days on semidefined medium at $20^{\circ} \mathrm{C}$ with a daily i $\mathrm{h}$ photoperiod

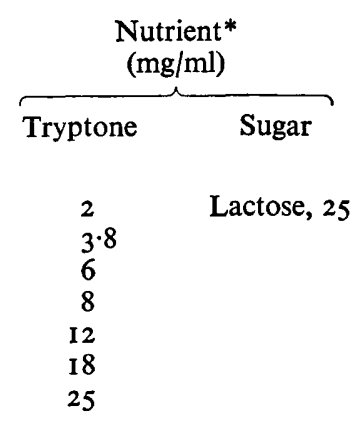

8

Lactose, 12
24
36
50
60

$3 \cdot 8$

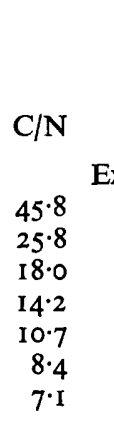

Dry wt

Experiment I

$5 \cdot 8$
$10 \cdot 0$
$12 \cdot 2$
$12 \cdot 5$
$7 \cdot 8$
$4 \cdot 8$
$3 \cdot 2$

Experiment 2

$8 \cdot 7$
13.7
18.8
24.7
28.9

Experiment 3

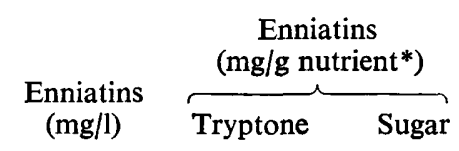

$\begin{array}{rrr}440 & 220 & 17.6 \\ 900 & 237 & 36 \cdot 0 \\ 1150 & 191 & 46 \cdot 0 \\ 1200 & \text { I 50 } & 48 \cdot 0 \\ 253 & 21 & 10 \cdot 1 \\ 180 & 10 & 7 \cdot 2 \\ 95 & 4 & 3 \cdot 8\end{array}$

$\begin{array}{rrr}581 & 73 & 48 \cdot 4 \\ \text { II47 } & 143 & 47 \cdot 8 \\ \text { I5I4 } & \text { I87 } & 42 \cdot 1 \\ \text { I724 } & 216 & 34 \cdot 5 \\ \text { I622 } & 202 & 27 \cdot 0\end{array}$

$\begin{array}{rrr}79 & 21 & 12 \cdot 6 \\ 360 & 95 & 28 \cdot 8 \\ 490 & 128 & 19 \cdot 6 \\ 187 & 49 & 3 \cdot 7\end{array}$

* In medium at time of inoculation.

In all three experiments, lactose conversion to enniatins was maximal at $\mathrm{C} / \mathrm{N}=\mathrm{I} 4$, and tryptone conversion was greatest at $\mathrm{C} / \mathrm{N}=25$. The highest absolute yield was from a medium containing $50 \mathrm{mg}$ lactose and $8 \mathrm{mg}$ tryptone per $\mathrm{ml}$, corresponding to $\mathrm{C} / \mathrm{N}=25$ (Table 9).

\section{DISCUSSION}

The results recorded here establish physical, physiological, and nutritional conditions conducive to the accumulation of large amounts of enniatins in the mycelium of Fusarium sambucinum HLX316. More than $95 \%$ of enniatins in mycelial extracts could be obtained crystalline (Audhya \& Russell, 1973d) by simple fractionation (Audhya \& Russell, 1973b).

No attempt was made to determine enniatins in the culture filtrate. Plattner et al. (1948) found $99 \%$ of enniatin A in the mycelium of Fusarium orthoceras, but Cook et al. (I949) obtained enniatins by extraction of the spent medium and found little activity in the mycelium. Both groups grew Fusaria at $25^{\circ} \mathrm{C}$; neither specified the conditions of illumination, but it seems unlikely that light was totally excluded. Tirunarayanan \& Sirsi (I957), who studied antibiotic production by $F$. avenaceum on glucose + sodium nitrate, observed that, when the $\mathrm{C} / \mathrm{N}$ ratio was low, antibiotic activity attributed to enniatin $\mathrm{B}$ appeared in the culture filtrate; when the $\mathrm{C} / \mathrm{N}$ ratio was $>7 \cdot 5$, all activity was in the mycelium. The media used by Plattner et al. (1948) and Cook et al. (1949) had C/N ratios of approximately 4 and I I respectively; this difference may account for their seemingly conflicting results. Tirunarayanan \& Sirsi (1957) attributed to cell lysis the ability of low $\mathrm{C} / \mathrm{N}$ ratio to promote the release of enniatin $\mathrm{B}$ into the medium, a suggestion supported by our finding of low dry weights and mycelial enniatin yields in cultures grown for 34 days on media with a low $\mathrm{C} / \mathrm{N}$ ratio (Table 9). 
The effects of light on microbial metabolism have received little attention. Many Fusaria require light for pigmentation (Zachariah, Hansen \& Snyder, 1956) and Bermingham, Deol \& Still (197I) reported a striking correlation between pigment (prodigiosin) formation and cyclodepsipeptide (serratamolide) synthesis by Serratia marcescens. Light absorption by pigment may be the first step in the chain of metabolic events leading to the formation of certain highly reduced compounds, such as enniatin and serratamolide.

The beneficial effect of low temperature on enniatin production is only slightly less obscure. It may be related to slower carbohydrate utilization favouring the pentose phosphate pathway over glycolysis (Saltero \& Johnson, I953; Hoštálek, I964) and thereby generating more NADPH to promote reductive biosynthetic processes. Consistent with this suggestion is the fact that lactose, which supported high enniatin yield, was the only carbon source not completely utilized in the comparative experiments.

This work, supported by grant MA2480 from the Medical Research Council of Canada and an award (to T.K.A.) from the Killam Trust, was the subject of T.K.A.'s doctoral thesis.

\section{REFERENCES}

AudHYA, T. K. \& Russell, D. W. (1973a). Enniatin Antibiotics from Fusarium sambucinum. Research Symposium of the Annual Meeting of the Association of University Faculties of Pharmacy of Canada, Dalhousie University, Halifax, N.S., 4-5 May, 1973, no. 3.

Audhya, T. K. \& Russell, D. W. (1973b). Production of enniatin A. Canadian Journal of Microbiology I9, 105I-I054.

AudhyA, T. K. \& Russell, D. W. (I $973 c$ ). Determination of branched-chain $N$-methylamino acids. Journal of Chromatography 84, 36I-370.

AUDHYA, T. K. \& RuSSELL, D. W. (1973d). Spectrophotometric determination of enniatin A and valinomycin in fungal extracts by ion complexation. Analytical Letters 6, 265-274.

AudhyA, T. K. \& Russell, D. W. (1974). Natural enniatin A, a mixture of optical isomers containing both erythro- and threo- $N$-methyl-L-isoleucine residues. Journal of the Chemical Society, Perkin Transactions I (in the Press).

Bermingham, M. A., Deol, B. S. \& STILL, J. L. (1971). The relationship between prodigiosin biosynthesis and cyclic depsipeptides in Serratia marcescens. Journal of General Microbiology 67, 319-324.

BrockmanN, H. \& SChMidt-Kastner, G. (1955). Valinomycin I. XXVII. Mitteillungen über Antibiotika aus Actinomyceten. Chemische Berichte 88, 57-6I.

Butler, G. W., Russell, D. W. \& ClaRKE, R. T. J. (1962). Incorporation of ${ }^{14} \mathrm{C}$-labelled amino acids into sporidesmolide I by Pithomyces chartarum (Sporidesmium bakeri). Biochimica et biophysica acta 58, 507-513.

CAPPellin, R. A. \& Peterson, J. L. (1969). Sporulation of Gibberella zeae. II. The effects of pH on macroconidium production. Mycologia 6r, 48I-485.

Chibnall, A. C., Rees, M. W. \& Williams, E. F. (1943). The total nitrogen content of egg albumin and other proteins. Biochemical Journal 37, 354-359.

Cook, A. H., Cox, S. F. \& FARMer, T. H. (1949). Production of antibiotics by fungi. IV. Lateritiin-I, Lateritiin-II, Avenacein, Sambucinin and Fructigenin. Journal of the Chemical Society, 1022-1027.

COOK, A. H., CoX, S. F., FARMer, T. H. \& LACEY, M. S. (1947). Production of antibiotics by Fusaria. Nature, London 160, 31-32.

Done, J., Mortimer, P. H., TAYLOR, A. \& Russell, D. W. (I96I). The production of sporidesmin and sporidesmolides by Pithomyces chartarum. Journal of General Microbiology 26, 207-222.

Dubois, M., Gilles, K. A., Hamilton, J. K., Rebers, P. A. \& Smith, F. (1956). Colorimetric method for determination of sugars and related substances. Analytical Chemistry 28, 350-356.

Gäumann, E., Roth, S., Ettlinger, L., Plattner, P. A. \& NAGer, U. (1947). Enniatin, ein neues, gegen Mykobakterien wirksames Antibiotikum. Experientia 3, 202-203.

Guérillot-Vinet, J., Guérillot-Vinet, A., GuYot, L., Montegut, J. \& RouX, L. (1950). Antibiotiques Sur une substance antibiotique extraite du mycélium de Gibberella baccata (Wallr.) Sacc. Comptes rendus hebdomadaires des séances de l'Académie des sciences $\mathrm{D}$ 230, 1424-I426. 
HALL, G. E. (1960). Identification of baccatin A as a mixture of enniatins A and B. Chemistry \& Industry, I 270.

HANES, C.S. (1929). An application of the method of Hagedorn and Jensen to the determination of larger quantities of reducing sugars. Biochemical Journal 23, 99-106.

HošłÁLEK, Z. (1964). Relationship between the carbohydrate metabolism of Streptomyces aureofaciens and the biosynthesis of chlortetracycline. I. The effect of interrupted aeration, inorganic phosphate and benzyl thiocyanate on chlortetracycline biosynthesis. Folia microbiologica (Praha) 9, 78-87.

Kiryushin, A. A., Rozynov, B. V. \& Ovchinnikov, Y. A. (I968). A mass spectrometric study of natural mixtures of enniatin antibiotics. Khimiia prirodnykh soedinenii 4, 182-1 86.

LACEY, M. (1950). The antibiotic properties of fifty-two strains of Fusarium. Journal of General Microbiology 4, I22-I3I.

LAMBERT, M. \& Neish, A. C. (1950). Rapid method for estimation of glycerol in fermentation solutions. Canadian Journal of Research 28B, 83-89.

MaCDonald, J. C. (1969). Production of valinomycin. Canadian Journal of Microbiology 15, 236-238.

OкоTORE, R. O. \& RUSSELL, D. W. (1972). Evidence of biosynthetical equivalence of the epimeric isoleucine residues in angolide. Canadian Journal of Biochemistry 50, 428-439.

Ovchinnikov, Y. A., Ivanov, V. T., Mikhaleva, I. I. \& Shemyakin, M. M. (1964). Synthesis of enniatin C. In Bulletin of the Academy of Sciences, USSR, Division of Chemical Sciences (Izvestiya Akademii nauk SSSR, Seriia khimicheskaia), p. I 823 .

Plattner, P. A. \& Nager, U. (I948a). Welkstoffe und Antibiotika. Analyse und Charakterisierung der Enniatine. Über das Verhalten von N-Methyl-aminosäuren in Papierchromatogramm. Helvetica chimica acta 3r, 2203-2209.

PlattNer, P. A. \& NAGer, U. (1948b). Welkstoffe und Antibiotika. Über die Konstitution von Enniatin B. Helvetica chimica acta 31, 665-67I.

Plattner, P. A. \& NAGer, U. (1948c). Welkstoffe und Antibiotika. Über die Konstitution von Enniatin A. Helvetica chimica acta 31, 2192-2203.

Plattner, P. A., Nager, U. \& Boller, A. (1948). Welkstoffe und Antibiotika. Über die Isolierung neuartiger Antibiotika aus Fusarien. Helvetica chimica acta 3I, 594-602.

Plattner, P. A., Vogler, K., Studer, R. O., Quitt, P. \& Keller-Schierlein, W. (I963). Synthesen in der Depsipeptidreihe: Synthese von Enniatin B. Helvetica chimica acta 46, 927-935.

Quitt, P., Studer, R. O. \& Vogler, K. (1963). Synthesen in der Depsipeptid-Reihe: Synthese von Enniatin A. Helvetica chimica acta 46, I 715-1720.

Russell, D. W. (1966). Cyclodepsipeptides. Quarterly Review, Chemical Society 20, 559-576.

Saltero, F. V. \& Johnson, M. J. (1953). The effect of carbohydrate nutrition on penicillin production by Penicillium chrysogenum Q-1 76. Applied Microbiology 1, 52-57.

Shemyakin, M. M., Ovchinnikov, Y. A., Ivanov, V. T., Antonov, V. K., Vinogradova, E. I., Shkrob, A. M., Malenkov, G. G., Evstratov, A. V., Laine, I. A., Melnik, E. I. \& Ryabova, I. D. (I969). Cyclodepsipeptides as chemical tools for studying ionic transport through membranes. Journal of Membrane Biology 1, 402-430.

Shemyakin, M. M., Ovchinnikov, Y. A., Kiryushkin, A. A. \& Ivanov, V. T. (I963a). The structure and total synthesis of enniatin B. Tetrahedron Letters, 885-890.

Shemyakin, M. M., Ovchinnikov, Y. A., Kiryushkin, A. A. \& Ivanov, V. T. (1963b). Synthesis of enniatin A. In Bulletin of the Academy of Sciences, USSR, Division of Chemical Sciences (Izvestiya Akademii nauk SSSR, otdelenie khimicheskikh nauk), p. 1055.

TAYLOR, A. (1970). The occurrence, chemistry, and toxicology of the microbial peptide-lactones. Advances in Applied Microbiology 12, 189-276.

TiRunarayanan, M. O. \& Sirsi, M. (I957). Antibiotics from the genus Fusarium enniatin B. I. Cultural studies and antimicrobial activity. Journal of the Indian Institute of Science 39, 185-194.

Zachariah, A. T., HANSEN, H. N. \& SNYDER, C. (1956). The influence of environmental factors on culture characters of Fusarium species. Mycologia 48, 459-467. 